Portland State University

PDXScholar

$11-17-2017$

\title{
From the Ground Up: the Intersection of Environment and Industry in Portland, Oregon
}

Madelyn Miller

Portland State University

Follow this and additional works at: https://pdxscholar.library.pdx.edu/honorstheses

Let us know how access to this document benefits you.

\section{Recommended Citation}

Miller, Madelyn, "From the Ground Up: the Intersection of Environment and Industry in Portland, Oregon" (2017). University Honors Theses. Paper 485.

https://doi.org/10.15760/honors.489

This Thesis is brought to you for free and open access. It has been accepted for inclusion in University Honors Theses by an authorized administrator of PDXScholar. Please contact us if we can make this document more accessible: pdxscholar@pdx.edu. 


\begin{abstract}
This thesis explores the relationship between industrial development and park creation during the first half of the twentieth century in Portland, Oregon. Beginning with an examination of early professional planning efforts of John Charles Olmsted alongside the economic boost brought by Lewis and Clark Exposition, this thesis traces the converging and diverging political and social efforts that formed Portland's Forest Park and Guild's Lake Industrial Sanctuary, using primary documents such as newspapers and planning reports to identify similarities and differences in how those two spaces came into existence. The creation of Forest Park came out of a reaction to expanding economic and industrial development, initially sparked by the Lewis and Clark Exposition a century earlier. At first glance, the Exposition celebrated the region's natural beauty, but in reality was also a tool used to show Oregon's promise as a vital player in opening global industrial markets. Clearance of large tracts of land, including the trees whose stumps gave Portland its "Stumptown" moniker, was a sign of the region's potential prosperity, and the destruction in Portland's hills and neighboring marsh were similar signs of progress, the new landscapes acting as symbols of the city's potential future prosperity. This research is rooted in William Cronon's analysis in "The Trouble With Wilderness; or, Getting Back to the Wrong Nature", that nature is a human-made concept and that the human and natural realms are in fact indistinguishable and interdependent. ${ }^{1}$
\end{abstract}

${ }^{1}$ William Cronon, "The Trouble With Wilderness; or, Getting Back to the Wrong Nature." In Uncommon Ground: Rethinking the Human Place in Nature, ed. William Cronon (New York: W.W. Norton, 1996), 69-90. 


\section{From the Ground Up:}

The Intersection of Environment and Industry in Portland, Oregon

by

Madelyn Miller

A thesis submitted in partial fulfillment of the requirements for the degree of

\section{Bachelor of Arts}

in

University Honors

and

History

Thesis Advisor

Catherine McNeur

Portland State University - Urban Honors College

2017 


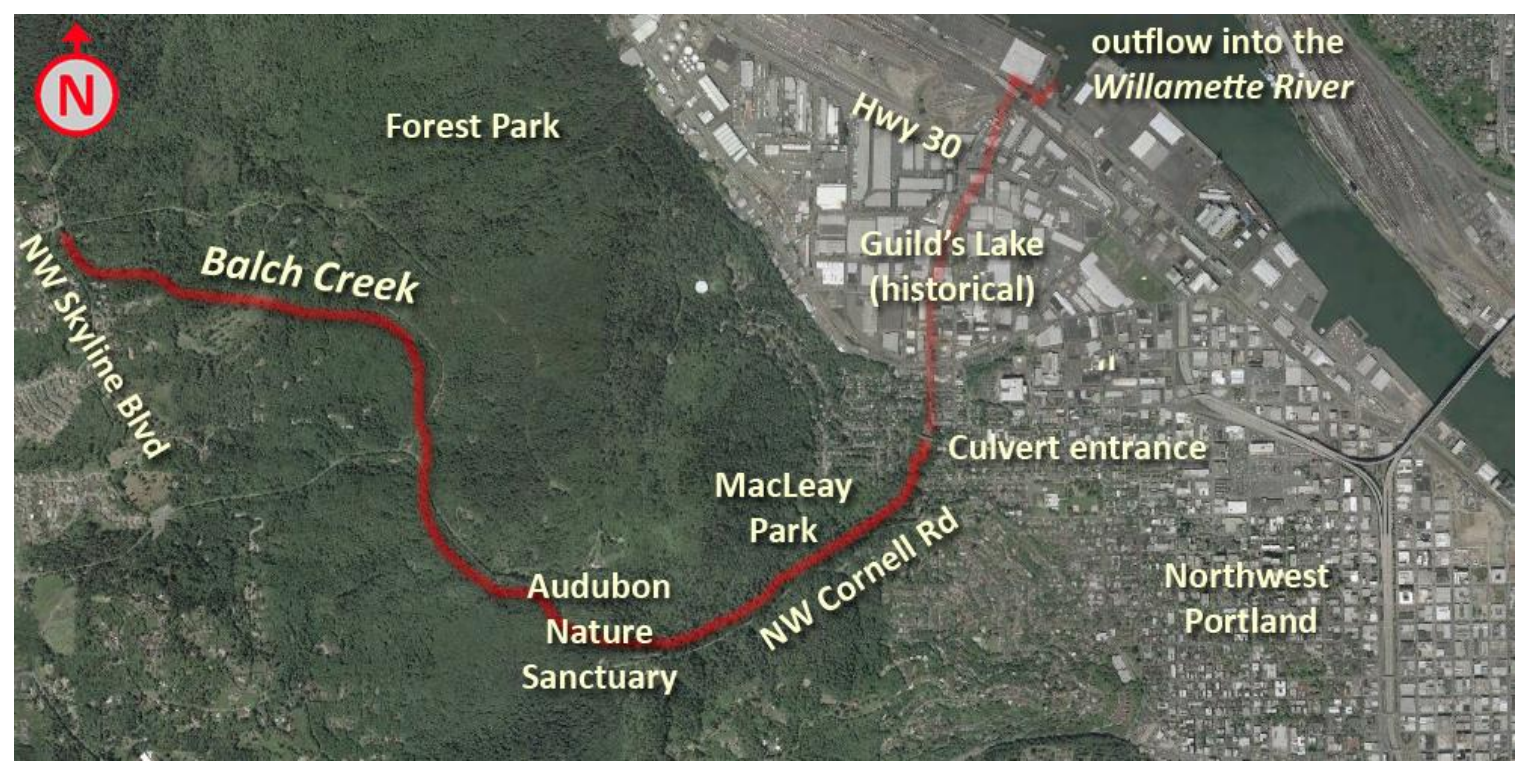

Map showing Balch Creek's path through Macleay Park and Guild's Lake Industrial Sanctuary United States Geological Survey, 2008.

\section{Introduction}

In 1905, at a site between a trash incinerator and a polluted floodplain, a crowd passed through a colonnade into the main plaza of the Lewis and Clark Centennial and American Pacific Exposition and Oriental Fair. Surrounded on all sides by Neoclassical and Renaissance-style buildings, the Exposition had an unmistakable aesthetic of power and prestige. Exhibits included halls dedicated to foreign nations, technology, agriculture, and industry, as well as rooms of both live animals and indigenous peoples living in simulated villages. Highlighting the natural, social, cultural and economic possibilities within Oregon, the goal of the Exposition was to show the promise of the state as a 
gateway to the newly opening markets of Asia and the South Pacific and as a vital player in the new global post-industrial economy. ${ }^{2}$ This industrial fervor ultimately, and somewhat counter intuitively, led to the creation of one of Portland's most celebrated spaces, Forest Park. Without industrial and economic development, Portland would have never developed the natural and recreation spaces it now prides itself on, and would have never gained its current reputation as an "ecotopia."”

Two years before the Lewis and Clark Exposition opened, landscape architect John Charles Olmsted, stepson of Central Park designer Frederick Law Olmsted, arrived in Portland with the task of designing a park system to rival those of East Coast cities. Planning officials had already chosen Guild's Lake, a marsh at the confluence of Balch Creek and the Willamette River, as the site of the fair when Olmsted arrived. After learning he was going to be visiting the city, the Fair's directors invited him to landscape the event so the site could potentially be incorporated into his greenbelt plan. Olmsted's Exposition design emphasized the natural features of the area, positioning lawns and ponds to perfectly frame and reflect Mount St. Helens and the tree line of the opposite bank of the river. ${ }^{4}$ The Exposition juxtaposed conspicuous leisure with the necessity of work and industry. To emphasize both of these themes, the exposition designers

\footnotetext{
${ }^{2}$ Lisa Blee, "Completing Lewis and Clark's Westward March: Exhibiting a History of Empire at the 1905 Portland World's Fair," Oregon Historical Quarterly 106:1 (2005): 232-253; Karin Dibling et. al. "Photo Essay: Guild's Lake Industrial District: The Process of Change Over Time,” Oregon Historical Quarterly 107:1 (2006): 88-105.

${ }^{3}$ Ellen Stroud, "Troubled Waters in Ecotopia: Environmental Racism in Portland, Oregon," Radical History Review 74 (1999): 65-95. Ernest Callenbach, Ecotopia (New York: Bantam Books, 1978).

${ }^{4}$ Blee, "Completing," 2005; Dibling et. al., "Photo Essay," 2006.
} 
displayed the region's natural environment as a tool of both recreation and productivity. The final design showed the pleasantries of nature, from Olmsted's manicured lawns and gardens to the views of the Willamette River and Mount Saint Helens, featured alongside the promise of Oregon's introduction to the world's economic and industrial stage.

Following the consolidation of Portland, East Portland, and Albina in 1891, a population and economic boom seemed more and more likely as spatial expansion opened the doors to new development opportunities. Speculators, investors, and businessmen looking for a chance to make a profit in the young city began arriving around the turn of the century, among them a Coloradan named Lafayette Pence, who had his eyes set on the hills of west Portland. ${ }^{5}$ Pence quickly devised a scheme to take advantage of the overlap of new development needs and the Exposition, predicting he could go unnoticed by city officials who had more pressing matters of urban design on their hands. ${ }^{6}$ Hoping to capitalize on the spirit of progress and enterprise many Portlanders felt at the turn of the century, Pence, a gold miner turned politician and by most accounts a swindler and crook, constructed a hydraulic sluice along Balch Creek in April of 1905 as part of a plan to level a section of the Willamette Heights neighborhood for residential development. His equipment cut a path through property along a tract

\footnotetext{
${ }^{5}$ Carl Abbott, "Greater Portland Experiments with Professional Planning, 1905-1925," The Pacific Northwest Quarterly, 76:1 (1985): 12-21.; Mansel Blackford, "The Lost Dream: Businessmen and City Planning in Portland, OR, 1903-1914," Western Historical Quarterly, 15:1 (1984): 39-56.

${ }^{6}$ Blackford, "The Lost Dream," 1984.; John Clark Hunt, "Forest Park: The Problems Did Not Begin Today," Northwest Magazine, September 27, 1970.; "Taken To Task Motives of Lafe Pence Discussed," Morning Oregonian, April 13, 1905.
} 
donated to the city by businessman Donald Macleay six years prior. Wanting to protect its limited park space and maintain the area's natural beauty, City Hall denounced Pence as a trespasser and asserted he had no right to use the water. ${ }^{7}$ Despite the Park Board's call for his arrest, Pence continued with his plans after the Fair ended, eventually encroaching into the Exposition grounds and Guild's Lake. The lake's proximity to both the Columbia and Willamette Rivers made it an ideal location for industrial development, and although Pence was forced to abandon the site after becoming entangled in a financial scandal, the area was entirely filled by another development company and evolved into what is now a part of the Northwest Industrial District.

In order to understand the relationship between industry and nature it is necessary to understand the relationship between humans and nature. Though sometimes positioned as distinct and adversarial, the human world and the natural world are ultimately one in the same, intertwined in a way that makes whatever happens to one eventually impact the other. In his seminal article "The Trouble With Wilderness," William Cronon argues that nature itself is in fact a human-made social construct, a way to distinguish the realm controlled and occupied by humans from the realms they have not yet ventured into. Cronon argues that to create this distinction is to ignore the relationship humans have with nature, and in turn ignore the ways in which humans impact and are impacted by the environments they occupy. The stories of Balch Creek, Guild's Lake, and Forest Park are examples of the way the human world and natural world are really one in the same, and

\footnotetext{
7 "Taken to Task"; "No Water Rights Nothing in Multnomah County Left for Pence," Oregonian, April 28, 1905.
} 
how without one the other would have never come into existence. ${ }^{8}$

The parallel histories of Guild's Lake and Balch Creek as sites of both the preservation and destruction of nature is a common narrative in the history of the relationship between industry and conservation in Portland. From professional planning to wartime industrial booms, the history of Portland's parks and natural spaces cannot be separated from its industrial and business-minded past. Without the industrial development of the first half of the twentieth century, Portland would not have the reputation as an environmentally conscious ecotopia it does today. ${ }^{9}$

\section{Early Park Development}

The story of the intersection between industry and environment in northwest Portland begins with two families, two bodies of water, and one murder. Peter Guild claimed the 600 acres of marshland that eventually hosted the Exposition and supported development in the west hills in 1847 under the Donation Land Claim Act, with the lake that eventually bore his family's name taking up about 220 acres of the plot. The Guild family used the area mainly as pasture space, and due to the instability of the soil the

\footnotetext{
${ }^{8}$ William Cronon, "The Trouble With Wilderness; or, Getting Back to the Wrong Nature." In Uncommon Ground: Rethinking the Human Place in Nature, ed. William Cronon (New York: W.W. Norton, 1996), 69-90.

9 "To Protect Its Beauty: Plans to Preserve Macleay Park in Its Native State," Morning Oregonian, August 23, 1902.; Stroud, "Troubled Waters," 1999.; Dibling et. al., "Photo Essay," 2006.
} 
swampiest parts of the land remained largely untouched. ${ }^{10}$ Around the same time the Guild family claimed their land, Danford Balch claimed a plot and adjoining creek just up the hill from the marsh. The forested hills looked little like they do today - a series of fires in the nineteenth century coupled with periods of over-logging left sparse patches and the occasional landslide. Despite the hill's scarred appearance, Balch's claim was still more desirable than Guild's Lake, if for no other reason than the latter contained a swamp, while Balch's claim did not. In the mid-nineteenth century, swamps, bogs, and floodplains had little value economically or culturally, mainly because of the difficulty managing them and their tendency to foster disease-carrying mosquitoes. ${ }^{11}$ Regardless of this undesirability, Manifest Destiny held fast in the minds of the American people and both families claimed their land under the promise of prosperity in the Oregon Territory.

The area and its inhabitants gained some notoriety long before Pence or Olmsted set foot in the state, when Balch's daughter Anna eloped with Mortimer Stump, the oldest son of a family in a neighboring plot. Balch expressed his disappointment in the union by cornering Stump on the Stark Street Ferry loading dock and shooting him point blank in the head, killing him instantly. Balch was arrested, but broke out of the city's flimsy wood plank jailhouse and escaped to the woods around his plot, where he remained hidden for nearly three months. ${ }^{12}$ Eventually, Balch was captured and sentenced to death,

${ }^{10}$ Dibling et. al., "Photo Essay," 2006.

${ }^{11}$ William G. Robbins, Landscapes of Promise: The Oregon Story, 1800-1940 (Seattle: University of Washington Press, 1997).

${ }^{12}$ Dibling et. al, "Photo Essay," 2006. 
becoming the first man legally hanged in Oregon. ${ }^{13}$ Balch's widow later sold their land, a large section of which was purchased by wealthy businessman Donald Macleay. Macleay donated the land to the city for use as a park just before his death in 1897, citing his desire for Portland to have more public green space. ${ }^{14}$ At the foot of the hill things were less eventful. In 1882 the Guild family parceled and sold their land, showing just how much the city had grown economically in less than a generation. Altogether, the property sold to various parties for $\$ 62,000$, over 13 times its original estimated value of $\$ 3,700 .{ }^{15}$ Despite the continued undesirability and poor reputation of marshlands, the Guild plot sale demonstrated Portland's burgeoning economic boom, as new prosperity in the city brought with it a demand for property, regardless of where or how desirable.

Control of the hundred acres surrounding Balch Creek did not transfer to the city for two years following Macleay's donation, as there was no official system of park management at the time. In February of 1899, the Oregon Legislature created the Board of Portland Park Commissioners, which allowed the city to levy taxes and enforce regulations relating to park matters. The Parks Board was placed in charge of the creation

\footnotetext{
${ }^{13}$ Charles Abbot Tracy, "Police Functions in Portland, 1851-1874: Part II," Oregon Historical Quarterly 80, no. 2 (1979): 134-69.

${ }^{14}$ For his generosity Macleay received a $\$ 15,000$ tax write-off, making the donation beneficial to all parties involved. "Macleay Park," Portland Parks \& Recreation, last modified 2016, https://www.portlandoregon.gov/parks/finder/index.cfm?action=ViewPark\&PropertyID= 246; Hunt, "Forest Park," 1970.

${ }^{15}$ Dibling et. al, "Photo Essay," 2006. ; "The Boom Increasing", Eugene City Guard, January 7, 1882; "Out at Guild's Lake," Morning Oregonian, April 29, 1902. Accounting for inflation, the property was initially purchased for $\$ 108,000$, and later sold for $\$ 1.6$ million.
} 
of future parks, which had proven in other cities to be one of the most effective ways of increasing urban property values. ${ }^{16}$ West Coast cities were status-conscious, often being compared to their larger and older East Coast counterparts, and in Portland this concern about reputation went hand in hand with the need to design and market the city to its fullest economic potential. ${ }^{17}$ Seeing parks as key to ensuring enduringly profitable property but uncertain of how to best develop a park plan on par with park-filled East Coast metropolises, in 1902 the Board hired John Charles Olmsted of the Olmsted Brothers landscape architecture firm to draft a design for Portland. After a weeklong tour of the city, Olmsted suggested a comprehensive master plan, composed of parks, playgrounds, and green spaces of various sizes and styles, connected by scenic drives and parkways. $^{18}$

\footnotetext{
${ }^{16}$ Blackford 1984; "History 1852-1900." Parks \& Recreation. 2016. https://www.portlandoregon.gov/parks/article/95955.

${ }^{17}$ William Deverell and Greg Hise. Eden by Design: The 1930 Olmsted-Bartholomew Plan for the Los Angeles Region. Los Angeles: University of California Press, 2000. 18 18 Blackford 1984.; Ann Whiston Sprinn, "Constructing Nature: The Legacy of Frederick Law Olmsted," in Uncommon Ground: Rethinking the Human Place in Nature, ed. William Cronon (New York: W.W. Norton, 1996), 91-113.; Olmsted, John Charles. City of Portland Parks Board Landscape Architects' Report. Report. Olmsted Brothers Landscape Architects, 1903.
} 


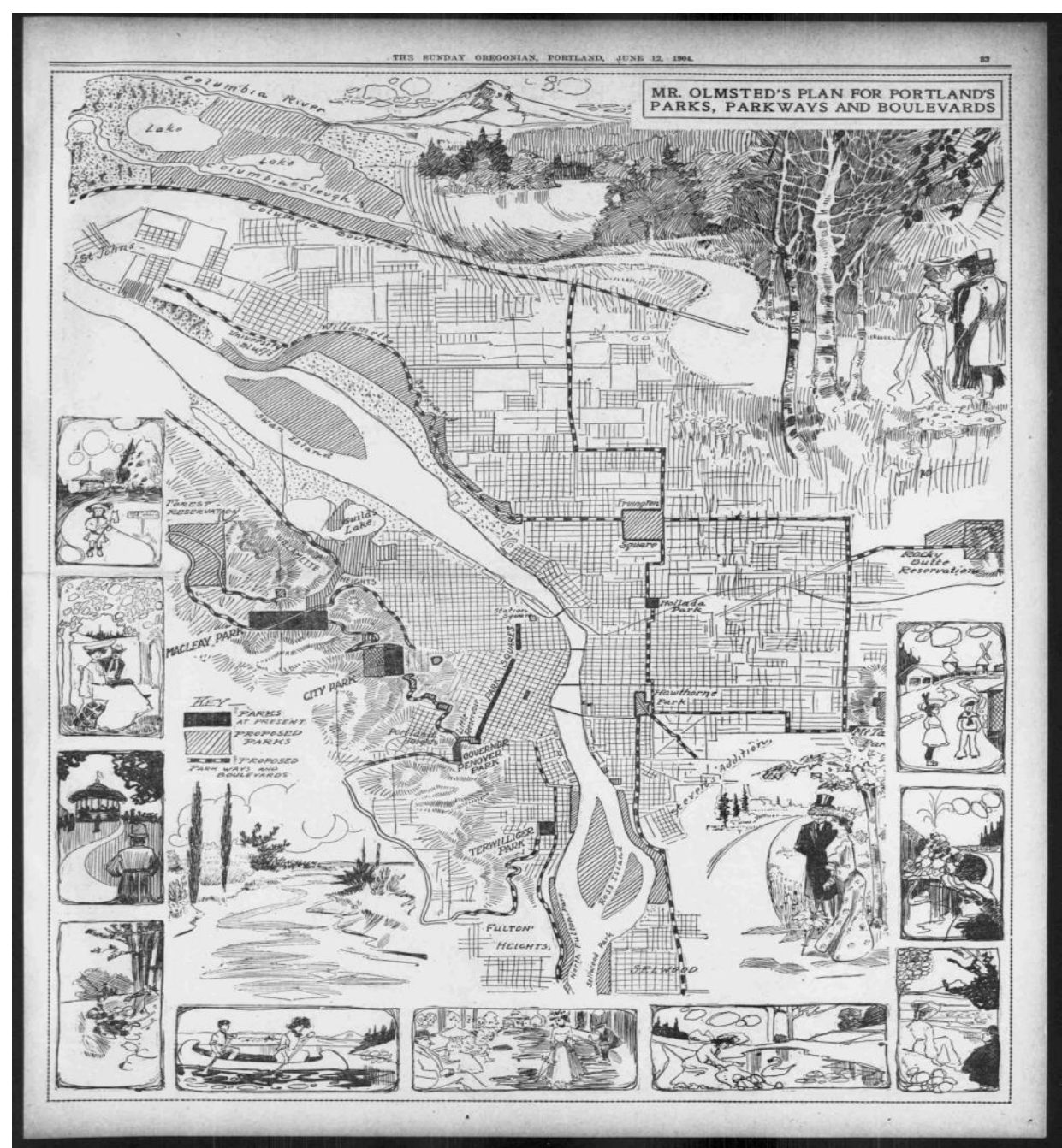

"Mr. Olmsted's Plan for Portland's Parks, Parkways and Boulevards." Sunday Oregonian, June 12, 1904.

Master plans for growing West Coast cities tended to take on an urgent tone, predicting the economic and social demise of a region if planners failed to enact the recommended measures. In addition to aiding city officials in decision-making, master plans were desirable because they made rapidly growing and expanding cities manageable and comprehensible, especially after decades of cities being seen as chaotic 
and unwholesome. ${ }^{19}$ Olmsted's plan, presented to the city in 1903, included Macleay Park and the surrounding area, which he suggested be kept in its wild and forested state with railed off walkways winding up the hill and onto Cornell Road to the west. He further suggested the park eventually be expanded into a larger forest preserve as he considered the moral and social benefits of a forest preserve outweighed economic needs, despite the desire of many Portland business leaders to develop the area for residential use. ${ }^{20}$ While city officials considered his recommendations and repeatedly referred back to his plan in the decades after his visit, very few of Olmsted's ambitious suggestions were ever implemented, as Portland's business elites saw profit and economic development as much more pressing matters.

Portland's earliest park plan came during a time when American landscape architecture was transforming, and the city's ultimate uncertainty of how to proceed with Olmsted's comprehensive design reflected the changing values placed on parks. In the latter half of the twentieth century planners imagined parks as pleasure grounds, meant to mimic an idealized countryside through intricately constructed spaces designed to look unstructured and rural. Loud and raucous activities outside of designated playing fields were not welcome, nor were restaurants, street vendors, or anything else associated with commercial activity and urban incivility. These parks followed the transcendentalist belief that nature was purifying and pacifying, so any activities considered immoral or

${ }^{19}$ Greg Hise and William Deverell, Eden by Design: The 1930 Olmsted-Bartholomew Plan for the Los Angeles Region (Berkeley: University of California Press, 2000), 3-7. ${ }^{20}$ John Charles Olmsted, City of Portland Park Board, Landscape Architects' Report, December 31, 1903.; Hunt, "Forest Park," 1970. 
corrupting were strictly banned. The era of park design that immediately followed embraced so-called reform parks, created in response to the refusal of children, street vendors, and the working class to stay in their place and out of the parks. Planners phased in louder and more physical sports, as well as inherently loud children's playgrounds, along with restaurants and swimming pools, reflecting the middle and working classes increased access to leisure time and changing ideas of childhood. ${ }^{21}$

Olmsted's park plan very much reflected the outmoded aesthetics of the pacifying parks and offered little in the way of playgrounds and athletic recreation, but that may have been only one of many reasons his plan never came to fruition. The very nature of the spaces he suggested be made into parks did not lend themselves to civility or orderliness, with the swampy, mosquito-filled Guild's Lake being a prime example of a landscape that would refuse, time and again, to do as it was told. City officials may have hesitated to implement Olmsted's designs not because they were exceptionally difficult, but because the landscapes he proposed did not match the nationwide shift away from beautification and towards profit-minded development. Nearly three decades later Olmsted's plan for Los Angeles, "Parks, Playgrounds and Beaches for the Los Angeles Area," recommended parks and recreation spaces not for their aesthetic or pacifying qualities, but based on their potential as tourist attractions, suggesting that while Olmsted

${ }^{21}$ Galen Cranz, The Politics of Park Design: A History of Urban Parks in America. (Cambridge: Massachusetts Institute of Technology Press, 1982). The creation of these more active and child-friendly parks was directly influenced by the playground movement, a facet of the urban reform movement that sought to steer young children away from the vices of urban life. 
did eventually shift his vision of landscape design, this shift came years after his Portland plan. $^{22}$

While Olmsted's suggestions for a park system occupied the Park Board, it was his design for the Lewis and Clark Exposition that most excited the rest of the city. World fairs had been extremely popular and profitable following the Great Exhibition in London in 1851 and the Chicago World's Fair in 1893, and in 1900 the state chose to host a similar event to mark the centennial of the completion of the Lewis and Clark expedition. ${ }^{23}$ Initially, the Fair's Board of Directors considered University of Portland or City Park as event sites, as these were already established recreation spaces, but they were not adequately connected to roads and streetcar lines and it would have cost an estimated $\$ 300,000$ to extend the tracks. Not wanting to spend the extra money, in September of 1902 the Board settled on Guild's Lake, the swampy home to the city's garbage incinerator. ${ }^{24}$

\footnotetext{
${ }^{22}$ Hise and Deverell, Eden by Design, 3

${ }^{23}$ Robert Rydell, All the World's A Fair: Visions of Empire at American International Expositions, 1876-1916 (University of Chicago Press. 1984).

24 "Excellent Location," Oregonian, May 19, 1901.; "Site for Lewis-Clark Exposition," New York Times, September 7, 1902.; Carl Abbott, The Great Extravaganza: Portland and the Lewis and Clark Exposition (Portland: Oregon Historical Society, 1981), 20.
} 


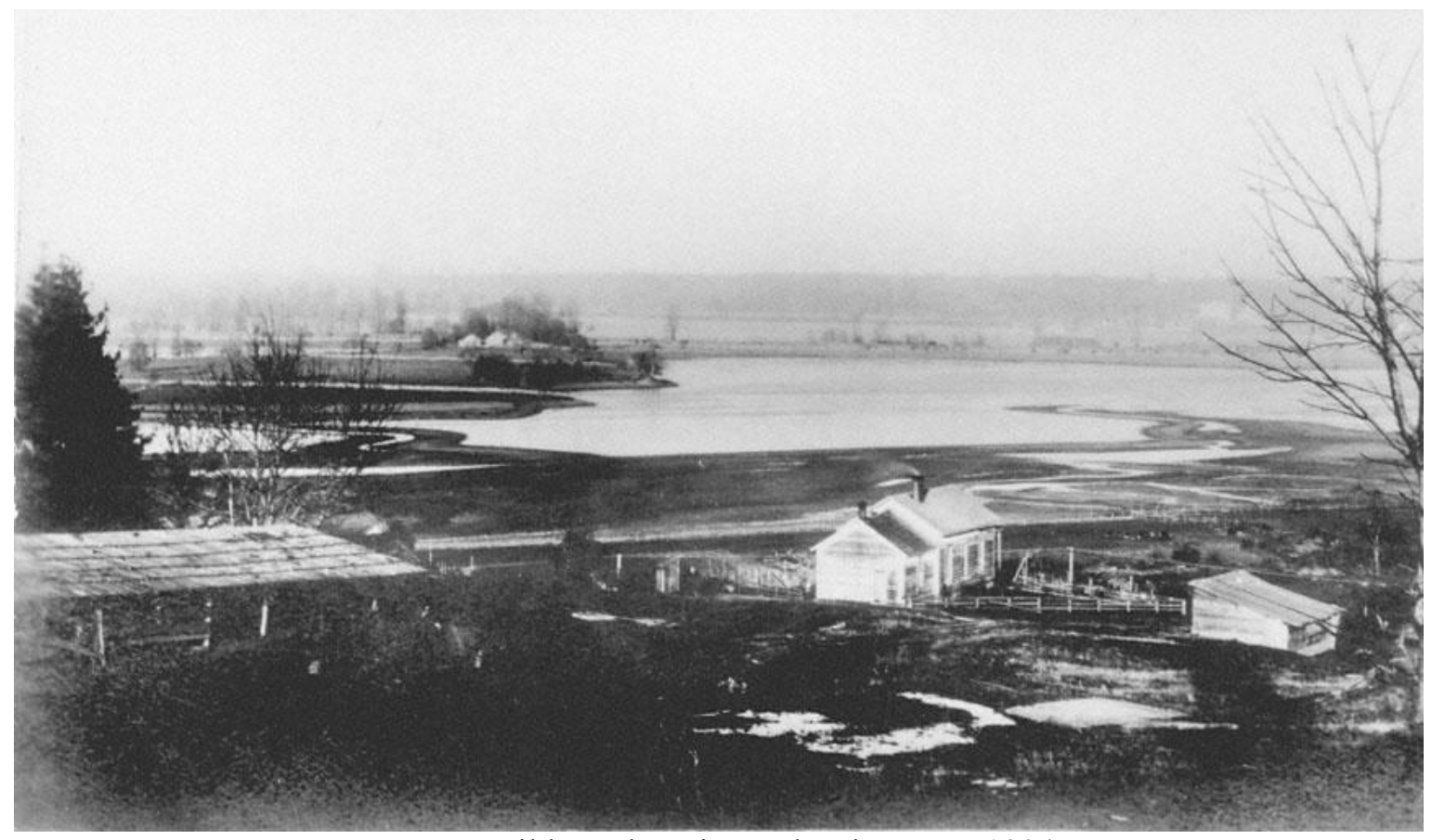

Guild's Lake prior to development, 1904.

Oregon Historical Society Research Library, OrHi 47291

Though the marsh itself was considered an eyesore, its location within the city was ideal. The streetcar lines along St. Helen's road would bring visitors directly to the fair from downtown, the lake had an unobstructed view of Mount Saint Helens to the northeast, and its proximity to the increasingly popular Macleay Park gave it additional appeal for out of town visitors. ${ }^{25}$ However, the lake was not without its reputation. In 1890 a young woman committed suicide by wading into the marsh until the mud was too thick for her to escape, and in 1894 the local milkman was found dead with a gunshot wound to his neck (the death was eventually ruled accidental), and just a few days prior confusion between neighbors over the ownership of a setting hen resulted in four counts

${ }^{25}$ Dibling et. al., "Photo Essay,” 2006; Olmsted, City of Portland, 1903. 
of larceny and three counts of assault and battery. ${ }^{26}$ These stories, coupled with the lake's reputation as home to Chinese squatter settlements and its proximity to the garbage incinerator, made the acquisition of Guild's Lake for the Lewis and Clark Exposition seem less like destruction or displacement and more like a public service. Noting that developing marshland was exceptionally expensive and labor intensive, and knowing most of the city's development budget would be focused on the growing East Side in the coming years, City Hall saw the fair as the best chance they would get to be able to afford development in the Guild's Lake area as subscriptions and outside donations would be the primary funding source for the event. In other words, the cost to the city would be manageable. ${ }^{27}$ Olmsted supported the lake as an exposition site, believing St. Helen's road could easily be turned into a scenic parkway and the rest of the area incorporated into the park system after the fair closed. ${ }^{28}$

The earliest uses of Guild's Lake and Balch Creek impacted how the city made later development decisions for each space. Guild's Lake's reputation as unmanageable land and home to undesirable residents made it easier to justify its acquisition and redesign. Balch Creek's reputation as the celebrated location of one of the region's first

\footnotetext{
26 “Setting Hens Cause A Neighborhood Row Near Guild's Lake," Oregonian, June 6, 1894.; "It Gave Up the Dead," Oregonian, June 23, 1890.; "His Death Accidental," Oregonian, June 22, 1894.

27 Abbott, "Greater Portland," 1985.; Olmsted, City of Portland, 1903.; Dibling et. al., "Photo Essay," 2006; Jewel Lansing, Portland: People, Politics and Power, 1851-2001 (Corvallis: Oregon State University, 2003).; Kenneth James Guzowski, Portland's Olmsted Vision (1897-1915): A Study of the Public Landscapes Designed by Emanuel T. Mische in Portland, Oregon (Master's thesis, University of Oregon, 1990).

${ }^{28}$ Dibling et. al., "Photo Essay," 2006.; Olmsted, City of Portland, 1903.
} 
urban forests, donated by one of the city's most influential businessmen, made it more difficult for City Hall to justify any development or destruction to park grounds. Despite these differences in perceived value, both spaces shared the experience of being included in the city's first foray into professional planning, which though ultimately not fully implemented, made the rapidly growing city seem more manageable and sparked decades of future plans for both parks and industry.

\section{Economic Optimism and Rogue Development}

Olmsted and the Park Board were not the only ones with grand plans for Northwest Portland, as Lafayette Pence had his eyes set firmly on Willamette Heights, the hilly neighborhood surrounding Macleay Park. Pence had been a U.S. Congressman, gold miner, prospector, lawyer, fervent Populist Party member and, when he first visited Portland in 1904, a delegate to a mining conference. He noted Portland's development potential and returned a few months later with his family to settle in the city semipermanently. Shortly after arriving in Portland, a warrant was issued for Pence's arrest in Salt Lake City for obtaining money under false pretenses, a detail somehow missed by Portland officials until months later. The charges brought to light more than a few ill feelings towards Pence in both Utah and Colorado, where he used his position in the American Mining Congress to swindle bankers and businessmen. ${ }^{29}$ Pence's charges and

29 "Warrant for Lafe Pence," Morning Oregonian, August 28, 1904. 
his uncanny ability to avoid punishment continued to be a common theme throughout his ventures in Portland.

In the spring of 1905, Pence filed for water rights on the Sandy River, Bull Run, and Johnson and Balch Creeks using a dubious loophole in the riparian code. Colonel LL Hawkins, Portland's Park Commissioner, quickly called foul on Pence's rapid and bold involvement in local development, accusing Pence of trying to secure a monopoly on local waterways to force the public to pay higher fees for water access. When asked his opinion of Pence by The Oregonian following a Multnomah County Commissioners meeting, Hawkins accused Pence of playing a "hold-up game" and called him a "mischief maker from the ground up." ${ }^{30}$ Pence eventually gave up his claims on the other bodies of water, shifting his focus solely on using Balch Creek to hydraulically level the Willamette Heights neighborhood, a project he began in 1905.

Although there had been large-scale development in Portland before, Pence's hydraulic leveling methods had not been approved by the city and he had not applied for permits or received inspections before beginning the work. Pence likely picked up the hydraulic sluicing method during his time as a gold miner, his plan being to redirect water from Balch Creek through high-pressure hoses to strip away the layers of dirt and soil that made up the hills of Willamette Heights, the area to the west of Macleay Park. ${ }^{31}$ The debris sloughed off the hill would be directed into a flume, an elevated chute leading down through Macleay Park and into the Willamette River (and, by default, into Guild's

30 “Taken to Task," Oregonian, April 13, 1905.

31 "Tear Down Hill Why Lafe Pence Wants to Use Water," Oregonian, April 16, 1905. 
Lake). In addition to their dislike of construction projects beginning without permits, City Hall took issue with Pence's leveling methods. Hydraulic mining had proven to be an environmental catastrophe in California fifty years prior, as the excess soil and debris built up along waterways, shorelines and riverbeds, causing flooding and the decimation of local ecosystems. ${ }^{32}$ While Pence could technically claim rights to develop along some small sections of the creeks and streams in the area, the section of Balch Creek he sought to control ran directly through Macleay Park, and the city made it clear they would take legal action if his venture impacted the creek in any way. ${ }^{33}$ Pence reassured officials that his only plan for Balch Creek was to use the water for grading in Willamette Heights, and, more immediately, to offer the water to the fire brigade stationed at the Lewis and Clark Exposition. Colonel Hawkins was not convinced by Pence's promises. A day after Pence's address to the County Commissioners, Hawkins surveyed the work being done around Balch Creek and found piping running directly through Macleay Park, where Pence had been forbidden to enter. Hawkins denounced Pence's actions and told The Oregonian that if any more work was done in the park illegally, Pence and his workers would be arrested for trespassing and damage to city property, adding: "Pence has so much gall he could fill a reservoir with it if he tapped it with a pipeline."34

Despite Hawkins' best efforts, Pence was not phased. He was working directly

\footnotetext{
${ }^{32}$ Raymond F. Dasmann, "Environmental Changes Before and After the Gold Rush," California History 77, no. 4 (Winter 1999): 105-22.; Andrew C. Isenberg, Mining California: An Ecological History (New York: Hill and Wang, 2006).

33 "Stops Lafe Pence," Morning Oregonian, April 15, 1905.

${ }^{34}$ Ibid.
} 
with the prominent property development company Russell \& Blyth, and what Pence lacked in trustworthiness they made up for in local influence. After Hawkins' warning, Percy Blyth threatened to shut off public access to the park, asserting that while the Board owned the park, his company owned the section of the creek that fed directly into the park's public entrance, which it would obstruct if necessary. When asked whether or not Pence or his company's development plans would damage Macleay Park, Blyth promised The Oregonian "[t]he park will not be injured to any extent. We simply want to cut down the hill. ${ }^{.35}$

Pence defended his intentions in the park, saying that without the sluice and flume running down the hill he would not be able to properly flatten the area of Willamette Heights he had planned for residential development. ${ }^{36}$ Two weeks later county judge Lionel R. Webster reviewed Pence's water claims and found they were entirely unfounded, as they consisted of Pence nailing a handwritten notice to a tree by the creek that claimed he had permission to work in the area. ${ }^{37}$ Pence brought another request to operate his flume to the Park Board three weeks after the Exposition opened in 1905, and the Board unanimously voted it down. Representatives from the Board claimed that to develop the site would be a direct contradiction to Donald Macleay's wishes, as he requested the area be kept in its natural state for public benefit. They told Pence he would be allowed to continue his development in Willamette Heights so long as he removed all

35 "Tear Down Hill Why Lafe Pence Wants to Use Water," Oregonian, April 16, 1905. ${ }^{36}$ Ibid.

37 "No Water Rights Nothing in Multnomah County Left for Pence," Oregonian, April 28, 1905. 
equipment from city-owned land. ${ }^{38}$

With little worry about the water rights saga taking place in the hills, the Lewis and Clark Centennial and American Pacific Exposition and Oriental Fair opened on the banks of Guild's Lake on June 1, 1905. The event had the common features of most world fairs, including street vendors, magicians, carnival rides, and food vendors. These more common sights were contrasted by the exhibit halls, statuary, lectures, and other displays of scientific and social innovation. The Exposition, as suggested by its longer title, was a commemoration of the 1805 Lewis and Clark expedition reaching the Pacific Ocean and securing in the minds Americans the idea of Manifest Destiny. With the markets of East Asia and the Pacific opening for trade, the Philippine-American War ending in 1902 with the Philippines becoming American territory, and the United States' acquisition of the Panama Canal construction project all happening within the previous decade, the economic possibility for the West Coast as a gateway to East Asia was an exciting prospect. ${ }^{39}$ For all of its anticipation about the opening Asian global trade, white Oregonians — like much of the rest of the country — were unquestionably prejudiced towards Asian peoples, a large community of which was displaced by the fair itself. In 1873 Portland City Council had passed the Cubic Air Ordinance, which barred any residences from housing more than one person per 550 cubic feet and required fine or arrest of all people living in such conditions. This was almost exclusively enforced in the

38 "Is Against Lafe Pence," Morning Oregonian , June 16, 1905.

${ }^{39}$ Blee, "Completing," 2005.; Blackford, "The Lost Dream," 1984.; Emily Trafford, "Hitting the Trail: Live Displays of Native American, Filipino, and Japanese People at the Portland World's Fair," Oregon Historical Quarterly 116, no. 2 (2015): 158-95. 
shanties near Guild's Lake and in Chinatown. ${ }^{40}$ In March of 1883, thirty Ku Klux Klan members raided a half dozen Chinese and Vietnamese farming settlements on the banks of Guild's Lake, burning houses and tearing up vegetable gardens and farming equipment. The attack sparked outrage and multiple Oregonian articles condemned the Klan's attack, but whether or not the farmers received any assistance after their farms were destroyed is unclear. ${ }^{41}$ Any irony of hosting a fair celebrating potential economic gain from East Asian markets on the site of an attack on an East Asian community went either unnoticed or unmentioned.

Optimism for the future occupied the city's collective consciousness during the summer of 1905, fueled by the promise of Oregon's natural resources in the opening global market. The state's rivers and coastline combined with its seemingly endless timber supply were major points of pride during the Exposition, as these resources would be the region's primary contribution to Pacific trade in the twentieth century. ${ }^{42}$ The displays and exhibits were the most telling of Oregon's opinion of the roles natural resources would play in development and expansion: exhibit halls featured rose test gardens that lauded the state's fertility and beauty; an ostrich farm showed the region was well suited for many types of fauna; rooms full of rocks and minerals and the equipment used to extract them showed Oregon would be able to compete with California's gold and Nevada's silver; and a makeshift nursery displayed babies born in local hospitals behind

\footnotetext{
${ }^{40}$ Lansing, "Portland," 146.

41 "Another KuKlux Raid," Oregonian, March 13, 1883.

42 Blee, "Completing," 2005; Trafford, "Hitting the Trail," 2015.
} 
a glass partition to show the health and strength of the state's future populations. ${ }^{43}$ One of the most impressive sights was the Forestry Building, a 20,000-square-foot log cabin that was unquestionably the centerpiece of the fair. Lumberman Simon Benson paid for the cabin, oversaw its design, and ensured that only the finest lumber was used in its construction. Inside were more trees and saplings native to the region as a celebration of the state's most economically promising natural resource. ${ }^{44}$

\footnotetext{
${ }^{43}$ City of Portland (OR) Archives, Souvenir picture book - Lewis and Clark Centennial Exposition. A2004-002, 1905. A promotional booklet published in Chicago in 1905, available at the Portland City Archives.; Pauline Oleo McClay, "My Trip to the Fair," Oregon Historical Quarterly 80, no. 1 (1979): 50-65.

${ }^{44}$ Abbott, The Great Extravaganza, 24.
} 


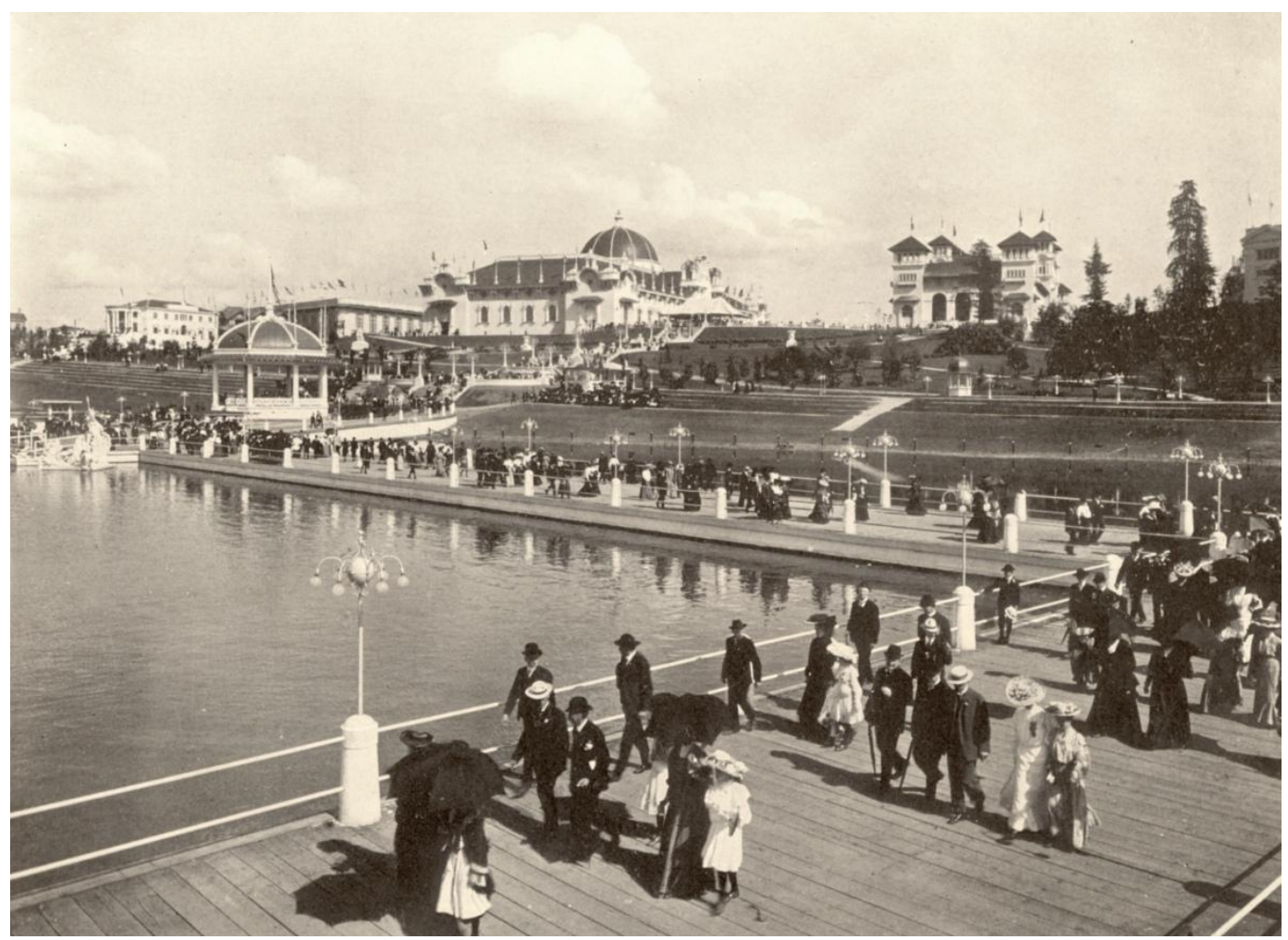

Guild's Lake during the Lewis and Clark Exposition, 1905.

City of Portland (OR) Archives, Lewis and Clark Exposition esplanade. A2004-002.1001, 1905.

The Exposition, ultimately, was a business venture that served to market the state to the rest of the country. ${ }^{45}$ The event brought $\$ 8$ million and 1.5 million people to the city, and the economic boom that followed was reflective of the expansionist rhetoric used during the fair celebrating Lewis and Clark and the mass settling of the West. The natural resources in the region were there for the taking, and with the Portland's population predicted to grow in the coming decades it would have seemed foolish for businessmen like Pence not to take advantage of the seemingly limitless development

45 Abbott, The Great Extravaganza, 14. 
opportunities. $^{46}$

Discussion of what should happen to the Exposition grounds began about a month before the event ended in October of 1905. Before the fair, ownership of a small fraction of the Guild's Lake site was divided between a handful of estates, and the rest was cityowned. The city contracted with the estates to sublease the land to the Exposition Board, but had not made any conclusive decision about the fate of the sections they controlled before the Exposition opened, leaving them scrambling to figure out what to do with the nearly 600 acres. The earliest plan was a request from the city to purchase the Forestry Building for use as a museum, and letters to Oregonian suggested City Hall buy the leased land and convert the whole area to permanent park space, following Olmsted's design. ${ }^{47}$ Despite the public's sentiment, deconstruction of the site began in November of 1905 when exhibit halls and display material were sold at public auction. ${ }^{48}$

Seeing an opportunity to make a profit while accelerating his sluicing, Pence purchased the Auditorium, Oregon Building, Agriculture Building, entry colonnade and emergency services station, in order to gain further access to the lake. He believed that if he could redirect the Willamette Heights debris from the river to the lake as infill, he

\footnotetext{
46 Abbott, "Greater Portland,” 1985; Blee, “Completing,” 2005; Blackford, “The Lost Dream," 1984.

${ }^{47}$ City of Portland (OR) Archives, C - Lewis and Clark Centennial Exposition. A2000003, 1905. Letter from Mayor Lane concerning to transfer of the Forestry Building to City of Portland.; O'Bryan, "Favors Fair Site for Park," Oregonian, October 12, 1905. 48 "Palaces Are Being Razed," Oregonian, November 06, 1905.
} 
would eventually have sellable land in both the West Hills and former Exposition site. ${ }^{49}$ The Park Board planned on preserving the Forestry Building as the sole relic of the fair, but in the months after the Exposition closed the rest of the swampy site seemed of less and less interest to public visitors. By 1906, Guild's Lake as the fairgoers had known it had more or less disappeared. After the dam was demolished the water level dropped by nearly ten feet, and the receding water revealed the lake had been used as a large garbage dump during the fair - the mudflat was littered with cans, food containers, broken memorabilia and other refuse from the event. ${ }^{50}$ The centerpiece of the city's most celebrated summer was suddenly an eyesore, and the site was eventually fenced off after multiple teenagers fell into the marsh and became stuck in the silt. ${ }^{51}$

Emboldened by his acquisition of the Exposition buildings, Pence decided to again expand his flume into the section of Balch Creek that cut through Macleay Park, despite the Park Board's decision that no form of development would be permitted on city-owned park grounds. ${ }^{52}$ The expansion once again did not go unnoticed. When Mayor Harry Lane got word of Pence's intrusion, he went directly to police headquarters and with the help of police Captain Bruin gathered a small party of officers and set out to Macleay Park. The officers were given sledgehammers and ordered to smash the twenty feet of piping intruding onto city property. Pence arrived at the scene of destruction

49 "Lafe Pence Buys Fair Buildings," Morning Oregonian, December 18, 1905.; "Close Fair Grounds," Morning Oregonian, January 29, 1906.

50 "Is Bare Mud Flat," Oregonian, February 12, 1906.

51 "Close Fair Grounds."

52 "Close Fairs Grounds."; "Lafe Pence Buyer," Morning Oregonian, December 30, 1905. 
shortly after the officers finished, and pleaded with Lane to be allowed to speak with the Park Board before any more of his equipment was destroyed. The Mayor was unmoved. He threatened Pence with arrest if he did not remove himself from city property. Pence left the scene and ordered his workers to go home for the rest of the day so as to not "stir up more trouble." Feeling that they had succeeded in their task, Mayor Lane and Captain Bruin celebrated Pence's departure by lighting cigars and practicing their marksmanship on a nearby tree..$^{53}$

The day after Mayor Lane's destructive trek into the park, it was clear some tension between Pence and City Hall had been alleviated. Mayor Lane, accompanied by an Oregonian reporter, an engineer, and a park superintendent, returned to the flume site to talk with Pence and discuss the previous day's incident. Pence greeted the mayor with a jovial "Hello Doc, the Ol' Wrecker!" and offered Lane and the police officers jobs tearing down his newly acquired exposition buildings, as they proved themselves adept with sledgehammers. Pence went on to explain that he knew the Board would never have approved his flume, so he built it anyway in the hope they would see its effectiveness at clearing the debris efficiently and allow him to keep it up. After some discussion Mayor Lane allowed Pence to proceed with his operation but instructed him to again petition that Park Board to make his operation legal. ${ }^{54}$

Mayor Lane's sudden switch from gallant park protector to a supporter of

\footnotetext{
53 "Smashes Flume of Lafe Pence" Morning Oregonian, February 26, 1906. 54 “Truce May End Flume Fight,” Morning Oregonian, February 27, 1906.
} 
destructive development did not sit well with Pence's critics. In a letter to the editor of The Oregonian, Mayor Lane clarified his position, explaining that the two had a meeting in December of 1905 where Lane gave Pence verbal permission to continue his project, but instructed Pence to petition the Park Board and secure the necessary permits before beginning any new sluicing or continuing any of the work he had already begun. Pence had ignored this and built the flume anyway, which Lane recognized as not only illegal but as a breach of trust and complete disrespect. Mayor Lane personally oversaw the destruction of the illegal equipment to make it clear to Pence that his insolence would not be tolerated. Furthermore, Mayor Lane explained he was worried that the precedent of not letting Pence develop Willamette Heights would compel future developers to skip Portland all together and go to Seattle or San Francisco when looking for west coast sites. Within a week of the Mayor's visit, Pence successfully petitioned the Board and was granted permission to continue the construction and operation of the flume. ${ }^{55}$ In a rare comment to The Oregonian, Pence lauded his victory, saying "I have harnessed the idle waters of west Portland... and have them at work making bad lands good...I expect to see these rough hills come down, I expect to see the worthless hollows and swamps filled up. ${ }^{56}$

Two months after his run-in with Mayor Lane, Pence purchased the Exposition's Government Building for $\$ 3,000$ with the intention of selling the site to a condensed milk manufacturer. He submitted plans to the city to build new streetcar and freight lines to the

55 “Truce May End Flume Fight."; "Mayor Lane Explains," Oregonian, March 1, 1906. 56 "Smashes Flume of Lafe Pence". 
area for ease of transportation and shipping. ${ }^{57}$ His proposal sent lines from downtown Portland up St. Helen's road, past Linnton and out as far as Cornelius, which even his most staunch detractors admitted would be an immense public service to the communities to the northwest of the city that lacked adequate transportation. ${ }^{58}$ Pence, The Oregonian conceded, had "the rare satisfaction of a man who watches his dreams come true."59 Despite this newfound support from City Hall and reluctant praise from local newspapers, Pence's reputation did not recover. In November of 1906 he secured an explosives permit to accelerate his grading in Willamette Heights, but it was revoked just a few days later when the impact of the blasting was found to be causing damage to surrounding homes. The city had given him permission to use 200 pounds of blasting powder at a time, but Pence thought he had found a loophole by using two 200-pound sets at once, making 400 pounds erupt early in the morning, shattering windows and jolting awake Willamette Heights residents. ${ }^{60}$ His reputation was further damaged when on February 2, 1907, a trestle under construction on a new section of his flume collapsed, killing one worker and seriously injuring four more. The men were working unharnessed 40 feet above Balch Creek when a support beam gave way, sending them plunging into the rocky dry creek bed below. Coupled with years of insolence in dealing with City Hall,

57 "Buy Government Building" Morning Oregonian, May 23, 1906; "Condensed Milk Factory," Morning Oregonian, May 24, 1906.

58 "New Line to Linnton," Morning Oregonian, April 5, 1906;

"Perspective Map Showing Route of Lafe Pence's Electric Line from Lewis and Clark Exposition Grounds," Oregonian, May 04, 1905; "Pence's Dreams Are Coming True," Morning Oregonian, March 11, 1907.

59 "Pence's Dreams Are Coming True".

60 "Engineer Revokes Pence's Permit," Oregonian, November 28, 1906. 
these incidents did not help Pence's reputation when a final unscrupulous decision ran him out of town less than six months later. ${ }^{61}$

In August of 1907, three years after coming to Portland, Pence put in an offer to purchase what remained of the fairgrounds outright, buildings, land, lake and all, for $\$ 300,000$, promising to use the remaining buildings as additional public exhibit and recreation spaces and to reserve the soon to be filled lake for mixed commercial and manufacturing uses. ${ }^{62}$ The city was not entirely opposed to Pence's development plans, but tensions were still high, and City Hall questioned where he was finding the money to fund these projects. Previously Pence had cited his benefactors as "Eastern capitalists," but he declined to clarify any further. He had carried out his sluicing project under the Colonial Investment Company, but many were skeptical that Pence's contract with them included an additional $\$ 300,000$ for a 660 -acre development project. ${ }^{63}$ In an unrelated inquiry in December of 1907, the District Attorney found the Title Guarantee and Trust Company, the parent bank of Colonial Investment, had been embezzling money from trust funds and savings accounts, then advancing the money to investors and subsidiary banks via carte blanche checks. Colonial Investment, as it turned out, was one of the primary recipients of these checks, and the investigation determined that Pence had already spent upwards of $\$ 400,000$ of embezzled money since arriving in Portland. ${ }^{64}$

\footnotetext{
61 "Workmen Carried Down With Bridge," Oregonian, February 2, 1907.

62 "Lafe Pence Will Buy Fairgrounds," Sunday Oregonian, August 4, 1907.

63 "Backers of Lafe Pence," Morning Oregonian, May 24, 1905; "Still Search for Lafe Pence," Morning Oregonian, August 18, 1908. 64 "Speculated with Trust Funds," Oregonian, December 08, 1907;
} 
Pence fled town shortly after this revelation, but the reports of exactly why are conflicting. Some claimed he was accepting the checks and embezzled money knowingly and returned to Colorado to avoid punishment, similar to how he had fled Utah less than a decade before. Others suggested he only had limited knowledge of where the bank's resources came from, and when it was shut down he was left with no financial resources to continue working in the region. Whatever his complicity, Pence was allowed to leave without punishment and, in true Pence fashion, without a word to any city officials or reporters what his plans were next. Before leaving he voided his rights to Willamette Heights and Guild's Lake and abandoned his sluice, escaping punishment but not infamy. ${ }^{65}$

The saga of Lafayette Pence's involvement in Northwest Portland development set the stage for the next half-century of the relationship between industry and environment. That Pence was allowed to continue his development project despite being censured multiple times shows how the city valued potential profit above much else. This half decade also brought with it a wave of support and concern for the park his development directly threatened, sparking a widespread appreciation, and the eventual physical expansion, of Macleay Park.

\section{Professional Planning and Economic Shifts}

"Bank Managed As Family Affair," Morning Oregonian, December 11, 1907.

${ }^{65}$ Hunt, "Forest Park," 1970. 
Guild's Lake, what remained of the Exposition site, and the Balch Creek flume sat untouched by development for a year after Pence left Portland. The lake had been filled to the point it would have been too expensive to be converted back to its natural state, and officials decided that completing the infill was the only economically viable future for the site. The city thus transferred control of the lake to the Lewis-Wiley Hydraulic Company, which temporarily reopened Pence's flume to finish filling the lake and leveling Willamette Heights. ${ }^{66}$ The new owners acknowledged the disappointment that the site would not be turned into park space, and in an effort to respect earlier visions for the area and to repair some of the reputation damage caused by Pence, Lewis-Wiley employed the Olmsted Brothers to aid in designing Willamette Heights and the spaces linking residential neighborhood, urban park and industrial site. The firm's new designs allowed for each residential lot to have unobstructed views of the city, river, or mountain, with park entrances tucked between lots and at the end of the major roads. ${ }^{67}$

Despite the Lewis-Wiley Company's best efforts, neither Balch Creek nor Guild's Lake wanted to cooperate. The hillside, stripped and overworked in the preceding decade, was prone to landslides, and what was left of the lake flooded frequently. When LewisWiley completed their work in Northwest Portland, Guild's Lake remained unstable with a sizeable section of marsh creeping back through the infill, causing cracks in the foundations of newly built industrial buildings and threatening the stability of rail lines.

\footnotetext{
${ }^{66}$ Dibling et. al., "Photo Essay," 2006.

${ }^{67}$ Dibling et. al., "Photo Essay," 2006. ; "Hill Being Moved.," Morning Oregonian, September 11, 1910.; "Hills Cut Down," Oregonian, November 19, 1909.
} 
Lewis-Wiley left ownership of the creek and lake to the city once the leveling and infill was completed, and Guild's Lake was for the first time in over a decade not under the control of a sole private developer, its fate uncertain as ever. ${ }^{68}$

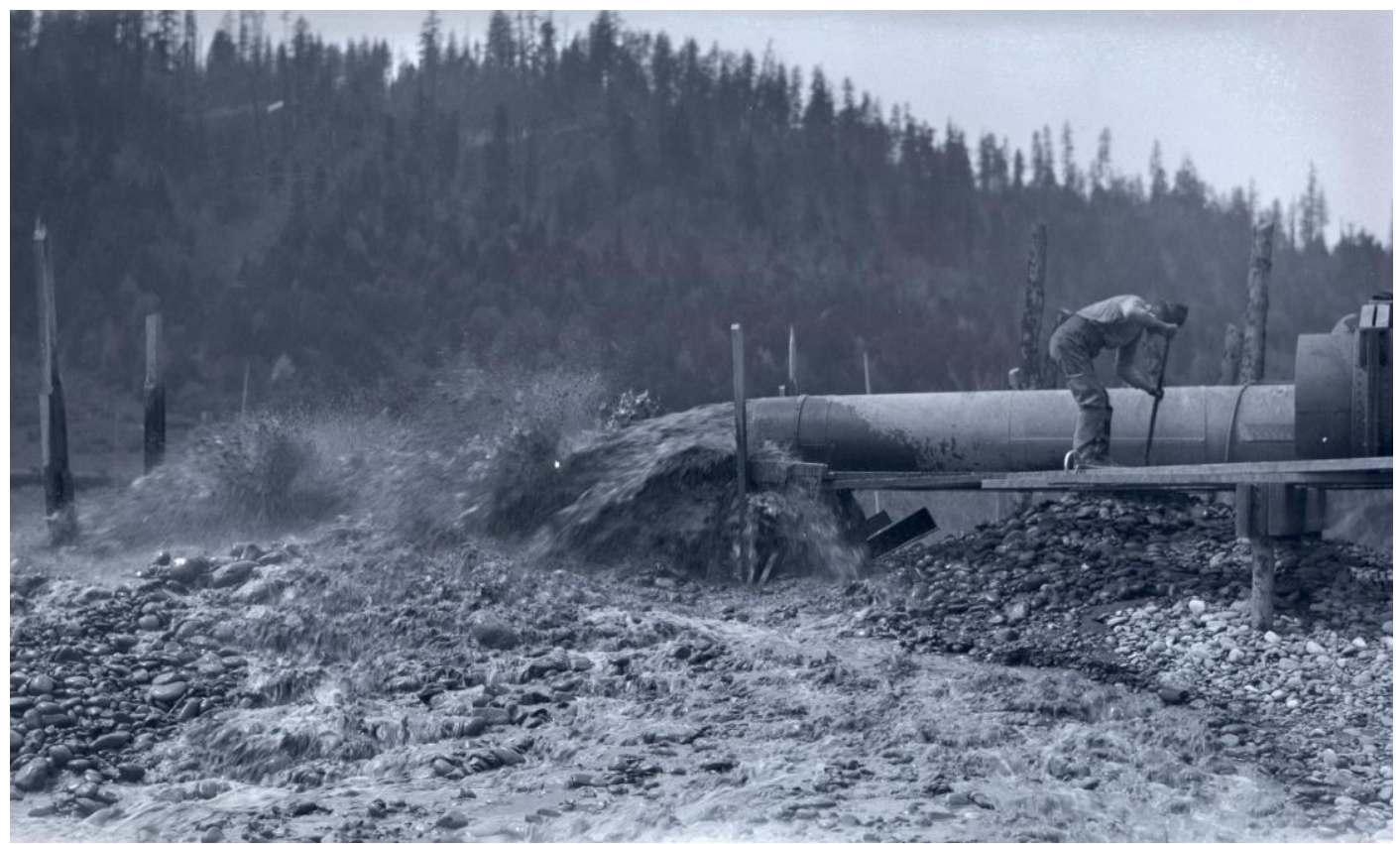

Debris from Willamette Heights filling Guild's Lake, April 21,1924.

Oregon Historical Society Research Library, bb006685

Wanting to use the newly-filled lake to its fullest potential but unsure how to best spark development in the area, city officials asked Edward Bennett to include the Guild's Lake site and neighboring Macleay Park in his 1912 Greater Portland Plan. The Portland Civic Improvement League hired Bennett, a noted architect and co-author of the 1909

68 Dibling et. al., "Photo Essay," 2006.; "Grade Underway," Oregonian, February 20, 1910; "Industrial Center Rises," Oregonian, December 07, 1913. 
Plan of Chicago, to create a comprehensive city-wide plan that included the economic and industrial designs John Charles Olmsted's plan left out. If Olmsted's plan was about beautifying, Bennett's was about optimizing. Bennett suggested that city developers focus on the waterfront, but to transform it to a manufacturing hub rather than public park space. He described Portland as a living organism, with the Willamette River as its primary artery, and suggested Guild's Lake and nearby Swan Island should be developed into deep-sea ports, with the filled parts of Guild's Lake serving as transportation and factory space for maritime manufacturing. His plan also encouraged the acquisition of new recreation space, proposing an additional 7,729 acres of public parks, including the undeveloped forest surrounding Macleay Park. ${ }^{69}$

Bennett's plan pushed parks further out, proposing "woodland or forest reserve areas" further from the river and accessible by street cars and new highways. ${ }^{70}$ While most of Bennett's plan was not implemented, a 1913 Park Board report echoed his insistence that the acquisition of public park space was essential before private developers bought the entirety of the city's most desirable land. ${ }^{71}$ Portland leaders, political and business alike, were business-minded but also recognized that the success of their businesses meant little if the city was not a desirable or pleasant place to live. ${ }^{72}$

Balch Creek nearly suffered a similar development-filled fate as Guild's Lake

${ }^{69}$ Abbott, "Greater Portland," 1985.; Edward Bennett, The Greater Portland Plan, 1912. ${ }^{70}$ Lansing, "Portland," 285.

${ }^{71}$ Annual Reports of the Park Board of the City of Portland Oregon 1908-1912. March 1913.

${ }^{72}$ Martha J. Bianco, "Robert Moses and Lewis Mumford: Competing paradigms of growth in Portland, Oregon," Planning Perspectives 16 (2001): 95-114. 
after the Lewis and Clark Exposition ended, but managed to escape irreversible destruction. Between 1900 and 1910 Portland's population more than doubled and developers considered the northwest hills prime real estate for wealthy newcomers. Following Pence's lead, Lewis-Wiley used water from the creek to resume leveling the area, and by the time they finished a decade of overuse left the creek almost entirely dried up. Once Guild's Lake was entirely filled in the early 1920s, the city removed the pipe system that followed the creek down the hill and added a grate and sewer line at its base in Lower Macleay Park to allow the water to again flow freely without flooding the trails. ${ }^{73}$ The city experienced a brief resurgence in park enthusiasm in 1915 when Park Board superintendent Emanuel Mische led tours through Macleay Park to encourage public interest in its expansion and improvement, but the failure of multiple park bonds and Mische's eventual resignation meant little work was done to in Macleay Park aside from basic upkeep. ${ }^{74}$

Portland's ability to secure funding for park development was further hindered when in 1918 World War I jump-started Portland's shipbuilding industry, leading to a housing shortage as thousands of workers moved to the area in less than a year. Seeking a

\footnotetext{
${ }^{73}$ This was nearly all the work done to the park, however, as recreational development was deprioritized as traffic congestion and overpopulation were deemed more tangible and pressing issues and the development of park space seemed a waste of resources in contrast. Dibling et. al., "Photo Essay," 2006.; E. Kimbark MacColl, The Growth of a City: Power and Politics in Portland, Oregon, 1915-1950 (Georgian Press. 1979), 321, 353.

${ }^{74}$ Melody Lynn Flowers, “A Comparative History of Three Urban Parks: The Bois de Bologne (Paris), Forest Park (Portland, Oregon) and Ueno Park (Tokyo)" (Master's thesis, Tarleton State University, 2001).; MacColl, The Growth of a City, 30.
} 
solution to this shortage, City Hall hired planner Charles Cheney to survey housing needs and develop a citywide solution. Cheney's first suggestion was to streamline and reduce industry expenses by creating designated industrial spaces, dividing the cost of initial development evenly between the public and private parties using those spaces. To improve the balance between industry and residential development he suggested zoning as the best way to consolidate and isolate industry, which gained him support from Portland's business leaders who saw zoning as a way to increase property value. Along with the newly formed "Committee of Fifteen", a City Hall-appointed group of business leaders tasked with revising waterway development, Cheney divided industry into two broad categories: "ordinary," which included warehouses and non-odor producing factories, and "obnoxious," which were odor, waste or noise producing. Cheney suggested these zones be categorized and located according to how much they would disrupt daily city life. Being removed from the central business district and located downstream along the north-flowing Willamette river, Guild's Lake was designated an "obnoxious" industry site, ideal for maritime and rail activity. ${ }^{75}$ After establishing Guild's Lake and a handful of other sites as obnoxious industrial zones, Cheney's role shifted from wartime industrial and residential planning to traffic and transportation design, and his report, Major Traffic Street Plan, Boulevard and Park System for Portland, Oregon became one of Portland's first implemented professional plans. Street widening and boulevard construction boomed in the 1920s, with the city building

${ }^{75}$ Dibling et. al., "Photo Essay,” 2006. 
multiple new roads and streetcar lines to connect outlying neighborhoods to the city center. ${ }^{76}$ In 1930 the creation of Yeon Avenue parallel to St. Helen's Road increased automobile and truck access to Guild's Lake, though not all of the companies in the industrial district were happy with the roadway expansions. A proposal to extend Front Street along the Willamette and through the district was met with resistance from Eastern \& Western Lumber in particular, which argued the public road would hinder the expansion of their warehouse space. This conflict between city and business suggests that the area was, for the first time since the before the Lewis and Clark Exposition, under at least partial control of private interests entirely separate from City Hall. ${ }^{77}$

Following the Great Depression, a decade after the implementation of Cheney's zoning plan, Portland once again sought the advice of professional planners to revitalize its economy. In accordance with New Deal-era regional planning philosophies, the Northwest Regional Council, a private planning and advocacy group, invited sociologist and urban theorist Lewis Mumford to Portland in 1938. Mumford was taken aback by Portland's over-reliance on technology and destructive development, and by how City Hall had repeatedly ignored or sacrificed the city's natural resources for economic gain. This failure to preserve natural spaces for public benefit was not lost on everyday Portlanders either: in 1930 the Morning Oregonian lamented the filling of Guild's Lake and development over Hawthorne Springs and Tanner Creek, contrasting these industrial and harmful development projects with the wild and unmanaged beauty of Macleay

${ }^{76}$ Bianco, "Robert Moses and Lewis Mumford," 2001.

77 “Guild's Lake Protests," Oregonian, July 03, 1929. 
Park. ${ }^{78}$ Mumford addressed the Portland City Club in 1938 and scolded Oregonians for neglecting to preserve their natural spaces, citing specifically the riverside industrial sites, including Guild's Lake. ${ }^{79}$ Mumford was critical of the "engineering mentality," or what he described as the privileging of technological advancement and efficiency over the social and natural world, a crime of which Portland was unquestionably a culprit. ${ }^{80}$ In addition to his dismay at the city's overzealous industrialization, he was concerned that the lack of regional thinking would lead Portland to become disharmonious and undemocratic. Mumford was a strong supporter of the Civilian Conservation Corps (CCC) and other agencies that sought to improve the recreational and cultural life of citizens, urban and rural alike. He noted the importance of ensuring these agencies and their activities remain funded after the New Deal ended in an address to the University of Oregon in 1938, saying that although the benefits of these projects were not as tangible as infrastructure projects, their results were greater because they improved human life. ${ }^{81}$ Similarly to John Charles Olmsted, Mumford proposed a greenbelt system to connect medium-sized pockets of population and Portland's urban core to parks and recreation opportunities, touting Oregon's wilderness as a national treasure for its outdoor and recreational opportunities. ${ }^{82}$ City Hall ultimately chose to not implement Mumford's plan, as it did not include specific suggestions they could use to change the city's landscape

78 "Natural Beauty and Progress," Morning Oregonian, August 1, 1930.

${ }^{79}$ Lansing. "Portland," 334.

${ }^{80}$ Francesca Russelo Ammon, Bulldozer: Demolition and Clearance of the Postwar Landscape (New Haven: Yale University Press, 2016), 193. 81 "Speaker Asserts Alphabet Bodies Very Significant," Oregonian, July 17, 1938. 82 "Wild Life Lines", Oregonian, December 23, 1934. 
while ensuring maximum profit. A budget-conscious government, coupled with a changeweary population, left Mumford's plan with the same unrealized fate as Olmsted's. ${ }^{83}$

\section{World War II and the Creation of Forest Park}

World War II sparked Portland's economy in a way nothing had before, and from this boom came further pushes for both industrial and recreational planning. Between 1940 and 1944 the city's population increased by $17 \%$ and Portland was once again recognized as a regional economic leader. The Lewis and Clark Exposition's prediction of the world's demand for Oregon's natural resources proved prescient: Oregon timber, hydraulic power, and shipbuilding brought both money and workers to the state in droves, resulting once again in a housing shortage in Portland where most of the shipyards and factories were located. ${ }^{84}$ By December of 1941 residential vacancy rates had fallen to $2 \%$. In an emergency measure City Council created the Housing Authority of Portland (HAP), though it was the Kaiser Shipbuilding Company, not HAP, that eventually met Portland's wartime housing needs ${ }^{85}$ Kaiser's largest housing development was Vanport, located between Portland and Vancouver, Washington, but second in size was the space Kaiser acquired on Guild's Lake, which eventually counted over 2,000

83 Bianco, "Robert Moses and Lewis Mumford," 2001.

${ }^{84}$ Lansing, "Portland," 308

${ }^{85}$ Ibid., 341 
homes, built at a total cost of $\$ 5,700,000 .{ }^{86}$. To make room for the new housing project, in 1941 the city ordered the demolition of the Depression-era shantytowns that dotted many of the unoccupied industrial lots, displacing an unknown number residents who mostly earned a living collecting scraps from the nearby garbage incinerator and industrial yards ${ }^{87}$ In 1948 HAP moved trailers and manufactured homes to the site after the Vanport Flood displaced 18,000 people. This influx of unemployed wartime industrial works and veterans put additional strain on Portland's housing market, but this reopening was only temporary and city officials assured nearby industries that as soon as newer developments were approved for habitation the site would again be cleared and reserved exclusively for industrial use. ${ }^{88}$

In this spirit of keeping Guild's Lake firmly industrial, the Works Progress Administration (WPA) created a new drainage system for Guild's Lake in the early 1940s to help mitigate flood damage to the area. Rail activity increased throughout the rest of the twentieth century after nine miles of tracks built during World War II transformed the area into one of the most prosperous industrial districts in the city as companies could transport goods from factories directly onto rail lines or ships. After the war, the Northern Pacific Railroad purchased the tracks and constructed facilities that soon employed thousands, ensuring Guild's Lake would be firmly situated in Portland's economy for

\footnotetext{
86 "Portlander's Housing Bid Low on Big Local Project," Oregonian, May 7, 1942.; "Guild's Lake Transformed By Huge Housing Project," Oregonian, May 30, 1943. 87 "Shanty Folk Glum Over Order to Move," Oregonian, June 29, 1941. 88 Abbott, "Greater Portland," 1985; "Board to Study Guild's Lake Problem," Oregonian, January 5, 1947.
} 
decades after the wartime boom. ${ }^{89}$

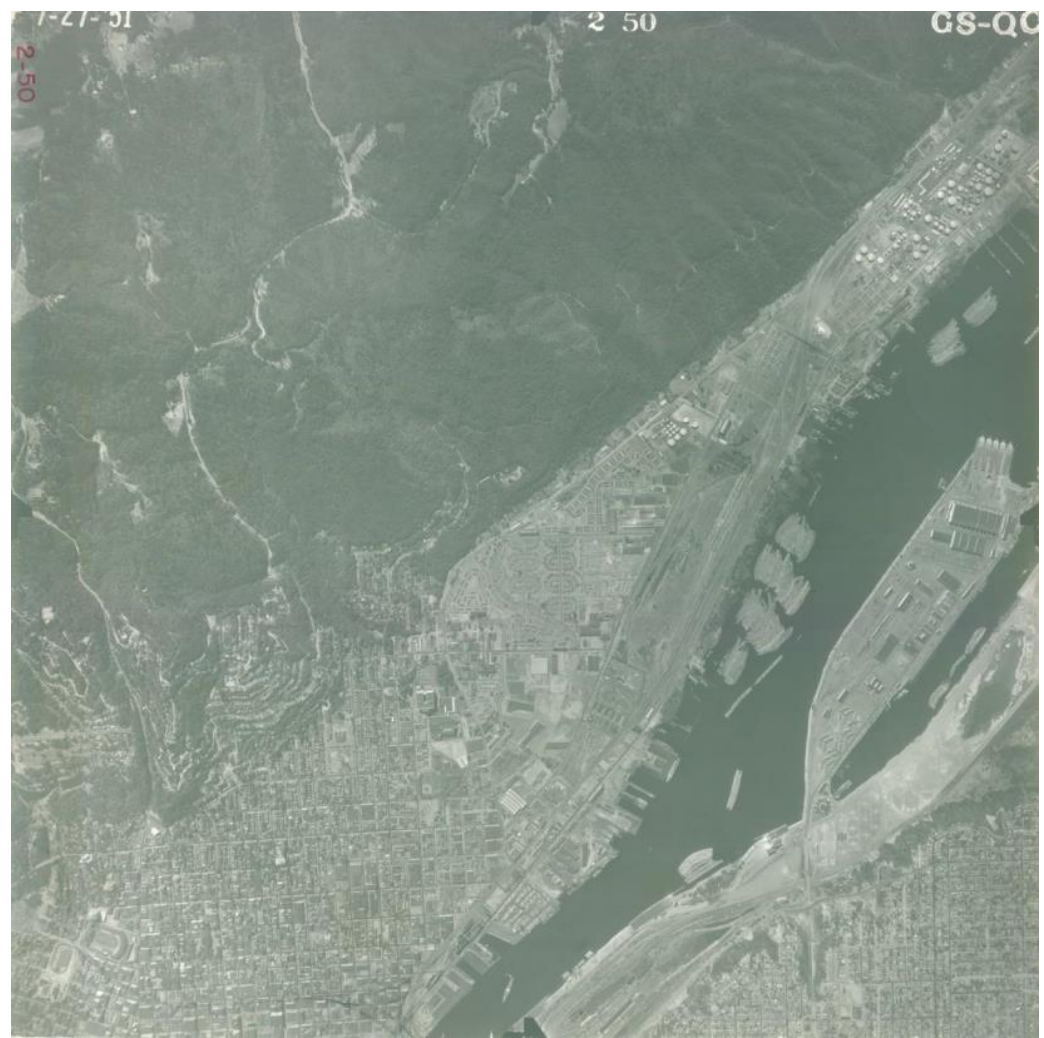

Aerial showing Guild's Lake Industrial District.

City of Portland (OR) Archives, Aerial photo map of NW Portland area. A2010-002.614, 1951.

While HAP and Kaiser handled the housing and livelihoods of Portlanders during wartime, the Park Board handled the much-needed morale boost. Between 1938 and 1941, participation in Park Board funded recreation programs tripled, at its peak serving an estimated 43,000 people a day. ${ }^{90}$ Excursions into the woods around Macleay Park and other nearby forests kept young adults occupied, and classes and camps taught

${ }^{89}$ Dibling et. al., "Photo Essay," 2006.

90 “Expanding Portland's Public Recreation,” Oregonian, October 10, 1948. 
stewardship and backpacking skills to men too young to be drafted. Harkening back to the late nineteenth century ideas of the pacifying and moralizing effects of park space, the Board hosted activities for youth and adults alike in an effort to reduce delinquency and increase patriotism for the war effort. ${ }^{91}$ In addition to keeping young people busy, involvement in local, state, and national parks created new interest in forest conservation that lasted after the war ended and contributed to the eventual creation of Forest Park in 1948. The forestry workshops and other outdoor programs were designed to mimic and complement traditional ideas of work and industry that to some seemed lost in urban communities, which in turn associated the space with the type of rugged individualism and an industrious quality that defined the Exposition. ${ }^{92}$

The impact of World War II on both Portland's population and demographics dramatically changed its planning needs less than a decade after Mumford's visit. The city's 17\% population increase between 1940 and 1944, coupled with the economic boom accompanying its wartime industries, left many both in and outside of City Hall thinking about Portland's post-war reality. Fear of a post-war recession, mass unemployment, and eventual population loss prompted the Portland Area Post War Development Committee to hire Robert Moses to design a post-war comprehensive plan for the apprehensive city. Moses was well known for his infrastructure projects on the East Coast, particularly New York City where he was head of the Parks Department. In describing Moses after City

${ }^{91}$ Lansing, "Portland," 342.; "Agencies Eye Youth Needs," Oregonian, September 22, 1944.

${ }^{92}$ David Mcleod, "Act Your Age: Boyhood, Adolescence and the Rise of the Boy Scouts of America," Journal of Social History, 2001. 
Hall announced the contract, The Oregonian emphasized his reputation as "the man who gets things done," and noted his ability to actually complete projects, something Portland officials had struggled with greatly. Nearly half a page of the Sunday Oregonian was dedicated to listing his achievements, honors, former positions, and education. The newspaper was undoubtedly optimistic about Moses' contract: "With Moses will come probably the most outstanding group of engineering and legal minds in this particular field." ${ }^{13}$ Moses proposed a $\$ 60$ million, 20,000-worker plan to build a freeway loop around downtown, improve sewers, expand the airport, renovate docks, and improve local schools. ${ }^{94}$

Moses' recommendations moved beyond the industrial. Harkening back to the earliest plans of John Charles Olmsted and Edward Bennett, Moses recommended the preservation, expansion, and improvement of the area around Macleay Park into a larger Forest Park. Whether because of the distance of time between reports or the fact the city spent $\$ 100,000$ in hiring him, Moses was credited with the proposal for Forest Park, despite John Charles Olmsted's recommendations forty years prior. ${ }^{95}$ Unlike each professional plan that came before it, Portland implemented almost all of Moses's recommendations, though some came decades later or were halted during later recessions. Unlike the plans drafted by Olmstead, Bennett, Cheney, and Mumford,

\footnotetext{
93 "'Man Who Gets Things Done' Placed in Charge Of Plans for Portland," Sunday Oregonian, August 29, 1943.

94 Lansing, "Portland," 344.; "Park Cost Cited," Oregonian, February 1, 1944. 95 "Forest Park in a City," Oregonian, September 9, 1943.; "Park Council OKs Decision," Oregonian, 1949 February 07.; "Wilderness Park Proposed for Evergreen City of the World”, Oregonian, July 28, 1948.
} 
Moses's was practical, tangible, and, most importantly to City Hall, profitable. Not unlike the development attempted by Pence before he fled the city, it was the projects that could concretely provide economic and industrial benefit to the city that were eventually approved to proceed. ${ }^{96}$

The Committee of Fifty, a citizen's interest council, formally requested the creation of Forest Park in July 1947. The first land added to the park was 1,400 acres the city owned from Depression-era foreclosures, followed by 11,000 acres transferred from Multnomah County. ${ }^{97}$ The majority of the land added to Forest Park came from Linnton, a formerly rural town bordering Guild's Lake to the north, which had been annexed by Portland in 1914 but left largely undeveloped. Linnton's economy had been promising in the first quarter of the twentieth century, having hosted many visitors during the Lewis and Clark Exposition, but the industrialization of Guild's Lake effectively cut off the neighborhood from the rest of the city. ${ }^{98}$

For a city swept up in development, public support for the creation of the park focused mainly on naturalness and an escape from industry. One reporter in July 1947 called the proposed park "a place for hikers to rest and poets to dream" and described potential viewpoints and pathways as threatened by nearby logging camps. Beauty and ugliness were firmly delineated: the logged areas and areas visibly altered by wildfires

\footnotetext{
96 Bianco, "Robert Moses and Lewis Mumford," 2001.

${ }^{97}$ Lansing, Portland," 348.

${ }^{98}$ Ibid., 298.
} 
were ugly, while the lush and quiet trails were beautiful. ${ }^{99}$ Another article published less than a year later lamented the logging done decades prior and praised the new growth and planting efforts as ways to "heal the scars of industry." Ironically, the same article quantified the amount of new growth in terms of potential boards of timber. ${ }^{100}$

This emphasis on the development potential of natural spaces was not uncommon coming out of two decades where destruction and growth were not mutually exclusive. In addition to the Depression era and wartime industries dramatically changing Portland's economy and demographics, the region's physical landscape had already been industrially altered in a way that set the stage for the creation of Forest Park. The WPA and Civilian Conservation Corps (CCC) spent the previous decade clearing other landscapes in the region for the creation of scenic and public-access spaces. Roads, rest stops, and day trip sites became wildly popular following the 1938 Federal Highway Act. Park creation experienced a renaissance in the 1930's as the CCC increased the country's state park space by $98 \%$, and within these parks the aesthetic was less constructed or obvious than the pleasure gardens from less than a century prior. Trails and structures rarely featured straight lines, local building materials were prioritized and the built environment was designed to blend into the pre-existing one. ${ }^{101}$ Forest Park, flanked on all sides by major roadways and dotted throughout with viewing areas and picnic sites,

\footnotetext{
99 "Camera Assesses Wealth,” Oregonian, July 07, 1947.

100 "Increase to Our Forest," Oregonian, May 25, 1948.

${ }^{101}$ Neil M. Maher, "Playing Politics at Bear Mountain: Franklin Roosevelt and the Civilian Conservation Corps," in Public Nature: Scenery, History and Park Design, ed. Ethan Carr, Shaun Eyring, and Richard Guy Wilson (Charlottesville: University of Virginia Press, 2013), 87-100.
} 
was perfectly suited to this aesthetic. ${ }^{102}$ Like the parks designed by the CCC, the goal was not necessarily the restoration of wilderness, but the restoration of the wellbeing of people. ${ }^{103}$ Much of the reforesting, trail creation and other initial maintenance in Forest Park was done by Boy Scouts and other groups that mirrored the efforts of the CCC, creating a sense of community pride in a space quickly considered one of Portland's best attractions. ${ }^{104}$

Despite City Hall's best efforts to separate Forest Park from its industrial origins and even more industrialized neighbor, Guild's Lake, the park was not without its intrusions and development attempts. Unsanctioned cutting by Christmas-tree seekers became a problem within a few years of the park's dedication, prompting the city to station police and guards around the park. ${ }^{105}$ A massive fire in 1951 prompted the evacuation of nearby residents and raised questions about how undeveloped the park really needed to be, as it lacked fire lanes or emergency service access. ${ }^{106}$ The solution to this problem was characteristically profit-minded: 825,000 of board feet of timber were put up for auction to make room for fire lanes and sold to the highest bidder to be harvested and used however they pleased ${ }^{107}$ Federal regulations on timber harvest made Douglas firs a particularly valuable commodity, and in a period where shifting

${ }^{102}$ Russello Ammon, Bulldozer, 185-6.

${ }^{103}$ Maher, "Playing Politics," 2013.

104 Ibid., 2013.

105 "Yule Tree Quest Menace to Park", Oregonian, December 15, 1953.

106 "Fire Fighters Battle to Save Woods, Homes in Northwest Portland," Oregonian, August 21, 1951.

107 “Lumber From Forest Park Offered At Auction,” Oregonian, February 8, 1952. 
relationships between business and regulation threatened the logging industry, the City insisted that the auction was a superb investment opportunity rather than resource destruction. ${ }^{108}$ The logging operation, irreverently named Operation Paul Bunyan, eventually removed a total of 1.3 million board feet from the park. ${ }^{109}$ As in the interwar and wartime periods, youth groups were tasked with the creation and maintenance of new trails and fire lanes once the trees had been harvested, and within two years following the fire, school age children planted 32,400 seedlings to reforest the burned park. ${ }^{110}$

The creation of Forest Park, despite its unmanicured and minimally managed appearance, was very much an industrial task, sparked and funded by an industrial boom. Discussions of its public benefit frequently circled back to its use by hard-working citizens as a site of rest and recovery, and its very creation and management mimicked the efforts of two of the country's largest-scale development organizations. Without the city's earliest residential development projects and later wartime industrial booms, Forest Park likely would never have been expanded to the thousands of acres it occupies today.

\section{Conclusion}

The back and forth between industrial development and environmental

\footnotetext{
${ }^{108}$ Robert E. Walls, "Green Commonwealth: Forestry, Labor and Public Ritual in the post-World War II Pacific Northwest," Pacific Northwest Quarterly 87, no. 3 (1996): 117-129.

109 "Hillsboro Logger Wins in Forest Park Auction," Oregonian, March 6, 1952.

110 "Students Plant 17,000 Seedlings in Burned-Over Forest Park," Oregonian, April 3, 1953.; “Junior Foresters Will Make Trails," Oregonian, June 12, 1952.
} 
conservation in twentieth-century Northwest Portland was no isolated incident in a city that markets itself as an ecotopia. The creation of Forest Park came out of a reaction to expanding economic and industrial development, initially sparked by a fair half a century earlier that at first glance celebrated the region's natural beauty, but in reality was also a tool used to show Oregon's promise as a vital player in opening global industrial markets. Lafayette Pence's rogue development scheme was reflective of the general mindset that the West had been won and, as promised by Manifest Destiny, was free for the taking to anyone industrious enough to develop the land. The fact that Pence was never punished for his trespassing suggests that the city was not opposed to his development plans and likely did not want to scare off future speculators and developers, knowing they would be vital to future economic growth. The subsequent destruction of Guild's Lake and the near-destruction of Balch Creek was the result of a city and its residents hoping to develop their way to economic prosperity by seeking the aid of professional planning, while only implementing the plans that promised economic and industrial growth. To make way for this new residential and industrial space, the transformed its environment by draining marshes and wetlands like Guild's Lake, leveling and landscaping hills, and driving creeks underground. While housing development efforts in Northwest Portland attempted to obscure the more industrial nature of the city and highlight urban wilderness, the Willamette Heights neighborhood could have never existed without industrial development, industry being both the source of funding and mode of physical creation of what was once hilly forest. Clearance of large tracts of land, including the 
trees whose stumps gave Portland its "Stumptown" moniker, was a sign of the region's potential prosperity. The destruction in Portland's hills and neighboring marsh were similar signs of progress, the new landscapes acting as symbols of the city's potential future prosperity. ${ }^{111}$

Hand in hand with industrial development planning came park planning as a means of increasing residential property values. John Charles Olmsted's 1903 plan was somewhat realized with the dedication of Forest Park in 1948, the creation of Tom McCall Waterfront Park in 1978, and the Eastbank Esplanade in 1998. Citywide policies, in particular during the governorship of Tom McCall in the 1970s, reflected the city's early ideas of the environment and economy being inextricably linked. The city marketed development projects like the creation of the waterfront park as "quality of life" measures that sought to improve not just ecosystems but the tangible day-to-day lives of people that interacted with them. The waterfront park was not just the restoration of a natural space, but also the creation of a new site of capital and consumption by Portlanders, not unlike the spaces created during the Lewis and Clark Exposition. The redevelopment of the waterfront and other previously industrial sites around Portland are in and of themselves a type of revenue source not dissimilar to the development efforts in the early twentieth century, as they are funded with the promise of being able to refashion and reshape spaces for a different, and arguably equally valuable, type of social capital that promises to create a happier populace. In comparing the development and planning philosophies of

${ }^{111}$ Russello Ammon, Bulldozer, 3. 
the early and late twentieth centuries, differences arise in definitions of purpose - earlier planners feared unprofitable use of natural resources, while planners in the latter half of the century sought solutions to development that hindered quality of life. Ultimately, both philosophies position industry and the use of natural resources right alongside environmental preservation. ${ }^{112}$ The story of Balch Creek and Guild's Lake is an example of this interplay between environment and industry, and shows how development and conservation are not mutually exclusive. To delineate or disconnect the two is to tell an incomplete story, one that ignores the impact of economics, politics, and planning on what are often a city's most celebrated spaces.

\section{Bibliography}

\section{Primary}

“Agencies Eye Youth Needs,” Oregonian, September 22, 1944.

112 Laura Jane Gifford, "Planning for a Productive Paradise: Tom McCall and the Conservationist Tale of Oregon Land-Use Policy," Oregon Historical Quarterly 115, no. 4 (2014): 470-501. 
Annual Reports of the Park Board of the City of Portland Oregon 1908-1912. March

1913.

"Another KuKlux Raid," Oregonian, March 13, 1883.

"Backers of Lafe Pence," Morning Oregonian, May 24, 1905.

"Bank Managed As Family Affair," Morning Oregonian, December 11, 1907.

Bennett, Edward. The Greater Portland Plan. January 1, 1912.

"Board to Study Guild's Lake Problem," Oregonian, January 5, 1947.

"The Boom Increasing", Eugene City Guard, January 7, 1882.

"Buy Government Building" Morning Oregonian, May 23, 1906.

"Camera Assesses Wealth," Oregonian, July 07, 1947.

"Close Fair Grounds," Morning Oregonian, January 29, 1906.

"Condensed Milk Factory," Morning Oregonian, May 24, 1906.

"Engineer Revokes Pence's Permit," Oregonian, November 28, 1906.

"Excellent Location," Oregonian (Portland), May 19, 1901.

"Expanding Portland's Public Recreation," Oregonian, October 10, 1948.

"Fire Fighters Battle to Save Woods, Homes in Northwest Portland," Oregonian, August 21, 1951.

"Forest Park in a City," Oregonian, September 9, 1943.

"Grade Underway," Oregonian, February 20, 1910.

“Guild's Lake Protests,” Oregonian, July 03, 1929.

"Guild's Lake Transformed By Huge Housing Project," Oregonian, May 30, 1943.

"Hill Being Moved.," Morning Oregonian, September 11, 1910.

"Hills Cut Down," Oregonian, November 19, 1909.

"Hillsboro Logger Wins in Forest Park Auction," Oregonian, March 6, 1952.

"It Gave Up the Dead," Oregonian, June 23, 1890.

"Increase to Our Forest," Oregonian, May 25, 1948.

"Industrial Center Rises," Oregonian, December 07, 1913.

"Is Against Lafe Pence," Morning Oregonian , June 16, 1905.

"Is Bare Mud Flat," Oregonian, February 12, 1906.

"His Death Accidental," Oregonian, June 22, 1894.

"Junior Foresters Will Make Trails," Oregonian, June 12, 1952.

"Lafe Pence Buyer," Morning Oregonian , December 30, 1905.

"Lafe Pence Buys Fair Buildings," Morning Oregonian, December 18, 1905.

"Lafe Pence Will Buy Fairgrounds," Sunday Oregonian, August 4, 1907.

Letter from Mayor Lane to The Lewis and Clark Exposition Commission for the State of Oregon. September 26, 1905. Portland City Archives, Portland, OR.

The Lewis and Clark Centennial Exposition and the Golden West. Chicago, 1905.

A promotional booklet published in Chicago in 1905, available at the Portland City Archives.

"Lumber From Forest Park Offered At Auction," Oregonian, February 8, 1952.

"'Man Who Gets Things Done' Placed in Charge Of Plans for Portland," Sunday

Oregonian, August 29, 1943. 
"Mayor Lane Explains," Oregonian, March 1, 1906.

"Natural Beauty and Progress," Morning Oregonian, August 1, 1930.

"New Line to Linnton," Morning Oregonian, April 5, 1906.

"No Water Rights Nothing in Multnomah County Left for Pence," Oregonian, April 28, 1905.

O’Bryan, Harvey. "Favors Fair Site for Park," Oregonian, October 12, 1905.

"Out at Guild's Lake," Morning Oregonian, April 29, 1902.

"Palaces Are Being Razed," Oregonian, November 06, 1905.

"Park Cost Cited," Oregonian, February 1, 1944.

"Park Council OKs Decision," Oregonian, 1949 February 07.

"Pence's Dreams Are Coming True," Morning Oregonian, March 11, 1907.

"Perspective Map Showing Route of Lafe Pence's Electric Line from Lewis and Clark

Exposition Grounds," Oregonian, May 04, 1905.

"Portlander's Housing Bid Low on Big Local Project," Oregonian, May 7, 1942.

"Setting Hens Cause A Neighborhood Row Near Guild's Lake," Oregonian, June 6, 1894.

"Shanty Folk Glum Over Order to Move," Oregonian, June 29, 1941.

"Site for Lewis-Clark Exposition," New York Times, September 7, 1902.

"Smashes Flume of Lafe Pence," Morning Oregonian, February 26, 1906.

"Speaker Asserts Alphabet Bodies Very Significant," Oregonian, July 17, 1938.

"Speculated with Trust Funds," Oregonian, December 08, 1907.

"Still Search for Lafe Pence," Morning Oregonian, August 18, 1908.

"Stops Lafe Pence," Morning Oregonian, April 15, 1905.

"Students Plant 17,000 Seedlings in Burned-Over Forest Park," Oregonian, April 3, 1953.

"Taken To Task Motives of Lafe Pence Discussed," Morning Oregonian, April 13, 1905.

"Tear Down Hill Why Lafe Pence Wants to Use Water," Oregonian, April 16, 1905.

"To Protect Its Beauty: Plans to Preserve Macleay Park in Its Native State," Morning Oregonian, August 23, 1902.

"Truce May End Flume Fight," Morning Oregonian, February 27, 1906.

"Warrant for Lafe Pence," Morning Oregonian, August 28, 1904.

"Wild Life Lines", Oregonian, December 23, 1934.

"Wilderness Park Proposed for Evergreen City of the World", Oregonian, July 28, 1948.

"Workmen Carried Down With Bridge," Oregonian, February 2, 1907.

"Yule Tree Quest Menace to Park", Oregonian, December 15, 1953.

\section{Images}

Aerial showing Guild's Lake Industrial District, July 27, 1951.

City of Portland (OR) Archives, A2010-002.614

Guild's Lake prior to development, 1904.

Oregon Historical Society Research Library, OrHi 47291 
Lewis and Clark Exposition esplanade, December 31, 1905.

City of Portland (OR) Archives, A2004-002.1001

Map showing Balch Creek's path through Macleay Park and Guild's Lake Industrial Sanctuary United States Geological Survey, 2008.

"Mr. Olmsted's Plan for Portland's Parks, Parkways and Boulevards." Sunday Oregonian (Portland), June 12, 1904.

\section{Secondary}

Abbott, Carl. "Greater Portland Experiments with Professional Planning, 1905-1925." The Pacific Northwest Quarterly, 76:1 (1985): 12-21.

--------The Great Extravaganza: Portland and the Lewis and Clark Exposition. Portland: Oregon Historical Society, 1981.

Ammon, Francesca Russelo. Bulldozer: Demolition and Clearance of the Postwar Landscape. New Haven: Yale University Press, 2016.

Bianco, Martha J. "Robert Moses and Lewis Mumford: Competing paradigms of growth in Portland, Oregon." Planning Perspectives 16 (2001): 95-114.

Blackford, Mansel. "The Lost Dream: Businessmen and City Planning in Portland, OR, 1903-1914." Western Historical Quarterly, 15:1 (1984): 39-56.

Blee, Lisa. "Completing Lewis and Clark's Westward March: Exhibiting a History of Empire at the 1905 Portland World's Fair." Oregon Historical Quarterly 106:1 (2005): 232-253.

Cranz, Galen. The Politics of Park Design: A History of Urban Parks in America. Cambridge: Massachusetts Institute of Technology Press, 1982.

Cronon, William. "The Trouble With Wilderness; or, Getting Back to the Wrong Nature." In Uncommon Ground: Rethinking the Human Place in Nature, ed. William Cronon, 69-90. New York: W.W. Norton, 1996.

Dasmann, Raymond F. "Environmental Changes Before and After the Gold Rush." California History 77, no. 4 (Winter 1999): 105-22.

Dibling, Karin et. al. "Photo Essay: Guild's Lake Industrial District: The Process of Change Over Time." Oregon Historical Quarterly 107:1 (2006): 88-105.

Gifford, Laura Jane. "Planning for a Productive Paradise: Tom McCall and the Conservationist Tale of Oregon Land-Use Policy." Oregon Historical Quarterly 115, no. 4 (2014): 470-501.

Hise, Greg and William Deverell, Eden by Design: The 1930 Olmsted-Bartholomew Plan for the Los Angeles Region. Berkeley: University of California Press, 2000.

Hunt, John Clark. "Forest Park: The Problems Did Not Begin Today." Northwest Magazine (Portland), September 27, 1970.

Lansing, Jewel. Portland: People, Politics and Power, 1851-2001. Corvallis: Oregon State University, 2003. 
MacColl, E. Kimbark. The Growth of a City: Power and Politics in Portland, Oregon, 1915-1950. Georgian Press. 1979.

Maher, Neil M. "Playing Politics at Bear Mountain: Franklin Roosevelt and the Civilian Conservation Corps," in Public Nature: Scenery, History and Park Design, ed. Ethan Carr, Shaun Eyring, and Richard Guy Wilson, 87-100. Charlottesville: University of Virginia Press, 2013.

McClay, Pauline Oleo. "My Trip to the Fair." Oregon Historical Quarterly 80, no. 1 (1979): 50-65.

Mcleod, David. "Act Your Age: Boyhood, Adolescence and the Rise of the Boy Scouts of America." Journal of Social History, 2001.

Robbins, William G. Landscapes of Promise: The Oregon Story, 1800-1940. Seattle: University of Washington Press, 1997.

Rydell, Robert. All the World's A Fair: Visions of Empire at American International Expositions, 1876-1916. University of Chicago Press. 1984.

Sprinn, Ann Whiston. "Constructing Nature: The Legacy of Frederick Law Olmsted," in Uncommon Ground: Rethinking the Human Place in Nature, ed. William Cronon, 91-113. (New York: W.W. Norton, 1996.

Trafford, Emily. "Hitting the Trail: Live Displays of Native American, Filipino, and Japanese People at the Portland World's Fair." Oregon Historical Quarterly 116, no. 2 (2015): 158-95.

Walls, Robert E. "Green Commonwealth: Forestry, Labor and Public Ritual in the postWorld War II Pacific Northwest.” Pacific Northwest Quarterly 87, no. 3 (1996): 117-129.

\section{Websites}

"Macleay Park," Portland Parks \& Recreation, last modified 2016, https://www.portlandoregon.gov/parks/finder/index.cfm?action=ViewPark\&PropertyID= 24

\section{Theses}

Flowers, Melody Lynn. "A Comparative History of Three Urban Parks: The Bois de Bologne (Paris), Forest Park (Portland, Oregon) and Ueno Park (Tokyo)." Master's thesis, Tarleton State University, 2001.

Guzowski, Kenneth James. Portland's Olmsted Vision (1897-1915): A Study of the Public Landscapes Designed by Emanuel T. Mische in Portland, Oregon. Master's thesis, University of Oregon, 1990. 
